\title{
Seabather's eruption: report of case in northeast region of Brazil *
}

\author{
Prurido do traje do banho: relato de caso na região nordeste do Brasil
}

\author{
André Luiz Rossetto ${ }^{1}$
}

\author{
Luís Antônio de Oliveira Proença²
}

\begin{abstract}
Seabather's eruption is characterized by the occurrence of intensely itchy erythematous papules observed mainly in the region covered by swimwear. The dermatitis occurs due to the contact of planula larvae of scyphomedusae Linuche unguiculata with the skin. The swimsuit pressure triggers the action of the poisonous stinging structures carried by the larvae. The case described occurred in a child who, while bathing in the ocean waters of the Northeast coast of Bessa's Beach located in the city of Joao Pessoa, state of Paraiba, showed typical clinical signs of the disease. It was concluded that the report of the case showed clinical and therapeutic implications for doctors working in all of the Brazilian coastal areas.
\end{abstract}

Keywords: Brazil; Cnidaria; Cnidarian venoms; Dermatitis

\begin{abstract}
Resumo: O prurido do traje de banho é uma erupção caracterizada por pápulas eritematosas, intensamente pruriginosas, localizadas principalmente sob os trajes dos banhistas de mar. A dermatite ocorre pelo contato com as larvas plânulas da cifomedusa Linuche unguiculata que disparam seus nematocistos na pele do acidentado a partir das suas células de defesa, os cnidócitos. O caso ocorreu em uma criança que ao se banhar nas águas oceânicas do litoral da Região Nordeste na Praia do Bessa localizada na cidade de João Pessoa, Estado da Paraíba, apresentou quadro clínico típico da enfermidade. Concluiu-se que o relato do caso evidenciou implicações clínicas e terapêuticas para os médicos que atuam em todas as áreas litorâneas brasileiras.
\end{abstract}

Palavras-chave: Brasil; Cnidários; Dermatite; Venenos de cnidários

\section{INTRODUCTION}

Seabather's eruption (SBE) is clinically characterized by intensely itchy erythematous papules observed mainly in the region covered by swimwear, while bathing or soon after exposure to seawater. ${ }^{1-4}$

The etiological agents of SBE are the planula larvae of scyphomedusa Linuche unguiculata (Figure 1). ${ }^{5}$ The planula larvae measure approximately $0.5 \mathrm{~mm}$ and the contact with the skin of the bather activates the nematocyst discharge from cnidocytes, $d$ defensive stinging cells, causing dermatitis.$^{1-6}$ The planula larvae penetrate the area covered by swimwear, are trapped by the material it is made of and discharge the cnidocytes mainly when the bather comes out of the ocean. ${ }^{1-6}$ Swimwear acts as a filter, draining water and keeping the planulae against the skin. It may also be triggered by contact with fresh water or pressure. ${ }^{1-6}$

This small jellyfish, with a diameter of approximately $1.5 \mathrm{~cm}$ is frequently found in the marine waters of the Caribbean, Gulf of Mexico, Florida, Cuba and Bahamas where many cases are reported and may even reach epidemic proportions. ${ }^{1.4}$

L. unguiculata was identified in the Brazilian coast in 1998 by Silveira and Morandini, in the São Sebastião Channel, state of São Paulo (SP). ${ }^{7}$ Some time later Morandini et al. identified it in the South Region, on the island where the Arvoredo Biological

Received on 31.03.2011.

Approved by the Advisory Board and accepted for publication on 10.07.2011

Work carried out at the University of Vale do Itajaí - Univali (SC), Brazil.

Conflict of interest: None

Financial funding: None

Dermatologist, Professor of Dermatology at the University of Vale do Itajaí - Univali (SC), Brazil.

Researcher at Instituto Federal de Santa Catarina IFSC, Campus Itajaí, Itajaí, SC SUBSTITUIR para 2Researcher at Instituto Federal de Santa Catarina IFSC, Campus Itajaí, Itajaí (SC), Brazil. 
Marine Reserve is located, in Florianópolis, state of Santa Catarina (SC); in the Southeast Region, on Ilha Grande, in Rio de Janeiro and in the Northeast Region, in the state of Ceará. ${ }^{8,9}$

In 2001 Haddad $\mathrm{Jr}$ et al. published the first Brazilian cases of SBE on the beach of Ubatuba, near São Sebastião Channel. ${ }^{2}$ Rossetto et al.(2007) reported six cases of the disease in the South Region, detected on beaches of Camboriú and Mariscal, located on the state of Santa Catarina coast and $45 \mathrm{~km}$ and $15 \mathrm{~km}$ away from the Arvoredo Biological Marine Reserve, respectively. ${ }^{3}$ According to Rossetto et al.(2009) the number of cases continues to expand, with thirtyeight cases observed involving six (42.8\%) of the fourteen municipalities in that seaside area. ${ }^{4}$

The typical clinical picture is characterized by a papulous, erythematous and pruriginous eruption that appears at the time of or soon after sea bathing, especially in the areas covered by swimwear, with progressive escalation of itching intensity. ${ }^{1,2}$ It usually affects children, suggesting longer time of exposure during sea bathing than adults. ${ }^{3,4}$

Diagnosis is both clinical and epidemiological. ${ }^{1 .}$ ${ }^{4}$ The main differential diagnoses are Swimmer's itch, that has its onset after fresh water bathing, strophulus and scabies. ${ }^{1-4}$

The use of topical vinegar has the effect of irreversibly deactivating $L$. unguiculata nematocysts, avoiding future discharges, but without effect on already released toxins. ${ }^{6}$ The illness responds well to treatment with systemic antihistamine and topical cor-

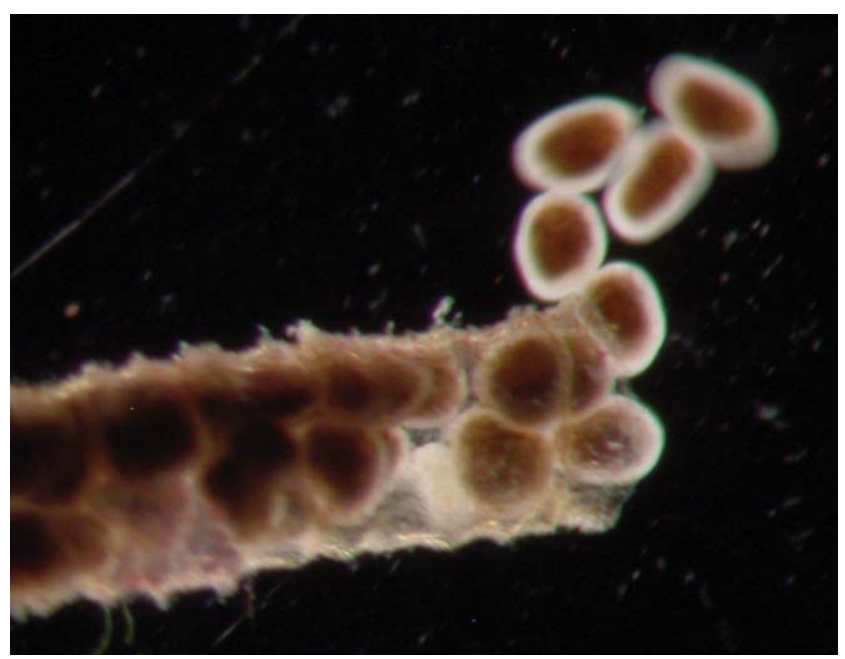

FIGURE 1: Macrophotograph of the extremity of a branch of the Linuche unguiculata colony collected at Ilha Grande, RJ (01/MAY/2005), from which it is possible to observe a few planula larvae discharged to the external environment after four days of observation. Enlarged 40X. Macrophotograph: Fabio Lang da Silveira, Department of Zoology, Institute of Biosciencies, Universyte of São Paulo/USP, state São Paulo (SP) ticosteroids and may evolve to spontaneous resolution in one or two weeks. ${ }^{1-4,6}$

The authors report a SBE case in a child, following sea bathing at the Bessa beach, located in the city of João Pessoa, state of Paraíba (PB), with the objective of highlighting and demonstrating the incidence of the disease in the Northeast Region of Brazil.

\section{CASE REPORT}

An 11-year old boy, resident of the city of Itajaí, state of Santa Catarina, presented with pruriginous lesions on the gluteal region for 12 days. The onset was immediately after sea bathing in the Northeast Region of Brazil, at the Bessa beach, in João Pessoa, PB, during the school vacation of January/2011. Itching and lesions were intensified at night and progressed to formation of some pustules. The patient continued to bathe on the same beach, with his father and brother, who were not affected. His parent took pictures of the lesions and when they returned to Itajaí they took the boy to the dermatology department to document the case (Figure 2). The physical examination detected erythematous papules with some pustules located on on the gluteal region and limited to places covered by the swimming trunks. Loratadine orally $10 \mathrm{ml} / \mathrm{day}$ and topical hydrocortisone were prescribed. He traveled again, did not use the medication and presented spontaneous recurrence of lesions in seven days.

\section{DISCUSSION}

In the present case the onset of erythematous papules was typical of the disease and due to the intense itching, some of them progressed to pustules. According to Rossetto et al. in an affected surfer the papules evolved to acneiform type lesions. ${ }^{4}$ The pla-

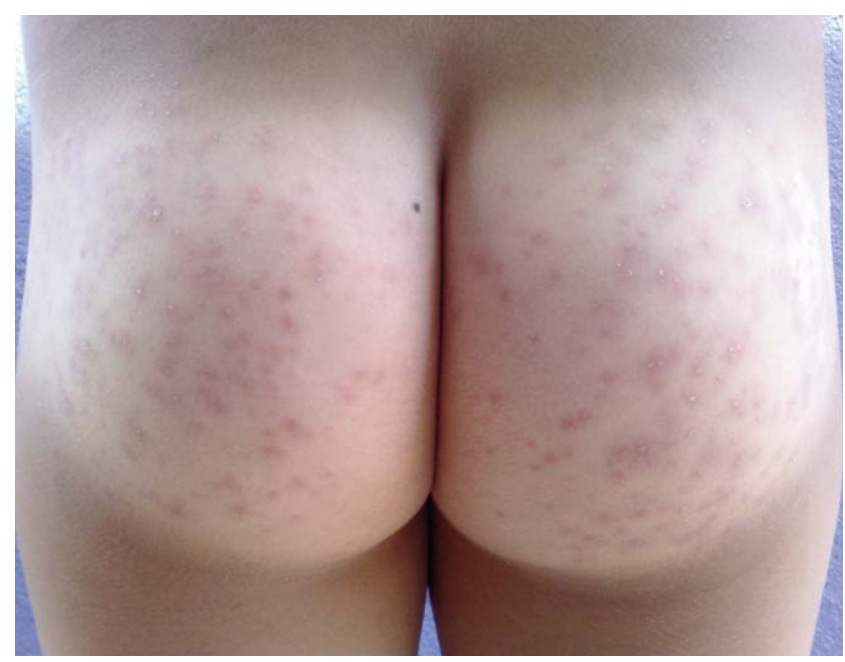

FIGURE 2: Presence of erythematous papules with a few pustules on areas covered by swimming trunks in the gluteal region 
nula larvae can penetrate most swimwear materials, including neoprene, worn by most surfers. ${ }^{4}$

SBE diagnosis is both clinical and epidemiological, laboratory tests are not necessary. The histopathological exam, although not characteristic, may corroborate for the diagnostic clarification of the illness on atypical locations, resistant to treatment and in surfers who have had several episodes due to prolonged reexposure to sea water. ${ }^{4}$

ELISA technique allows the demonstration of specific reactivity with $L$. unguiculata IgG-class antibodies in the serum of the patients, but it is not available in our midst. ${ }^{10}$ Rossetto et al. stocked serum of most $(60.5 \%)$ of the thirty-eight affected patients for future serology tests. ${ }^{4}$ In the reported case serum was not collected for laboratory tests.

According to Haddad $\mathrm{Jr}$ et al. the incidence of this dermatitis in Brazil is probably underestimated, since many do not seek medical attention. ${ }^{1,2}$ This is possibly due to the fact that the disease, in some patients, such as in the reported case, progresses to spontaneous resolution and is frequently unknown to part of the population and health professionals. ${ }^{1-4}$

It was concluded that, one decade after the first SBE report in the country, five years since the identification of $L$. unguiculata in the Northeast, it seems clear that this dermatitis is not restricted to the Southeast and South Regions of Brazil. ${ }^{2,9}$ Its presence in the Northeast coast is evidence that the disease occurs, with clinical and therapeutic implications for physicians that work in seaside areas of all the country.

\section{ACKNOWLEDGMENTS:}

To Professor Fabio Lang da Silveira, Department of Zoology, Institute of Biosciencies, Universyte of São Paulo/USP, state São Paulo (SP) for allowing the use of macrophotograph of Linuche unguiculata.

\section{REFERENCES}

1. Haddad Jr V. Animais Aquáticos Potencialmente Perigosos do Brasil: Guia Médico e Biológico. São Paulo: Editora Roca; 2008. p12-41.

2. Haddad Jr V, Cardoso JLC, Silveira FL. Seabather's eruption: report of five cases in southeast region of Brazil. Rev Inst Med Trop Sao Paulo. 2001;43:171-2.

3. Rossetto AL, Mora JJ, Correa PR, Resgalla Jr C, Proença LAO, Silveira FL, Haddad Jr V. Prurido do traje do banho: Relato de seis casos no Sul do Brasil. Rev Soc Bras Med Trop. 2007;40:78-81.

4. Rossetto AL, Dellatorre G, Silveira FL, Haddad Jr V. Seabather's Eruption: a clinical and epidemiological study of 38 cases in Santa Catarina State, Brazil. Rev Inst Med Trop Sao Paulo. 2009;51:169-75.

5. Black NA, Szmant AM, Tomchik RS. Planulae of the scyphomedusa Linuche unguiculata as a possible cause of seabather's eruption. Bulletin of Marine Science. 1994;54:955-60.

6. Segura-Puertas L, Ramos ME, Aramburo C, Heimer De La Cotera EP, Burnett JW. One Linuche mystery solved: all 3 stages of the coronate scyphomedusa Linuche unguiculata cause seabather's eruption. J Am Acad Dermatol. 2001;44:624-8.

7. Silveira FL da, Morandini AC. Asexual reproduction in Linuche unguiculata (Swartz 1788) (Scyphozoa: Coronatae) by planuloid formation through strobilation and segmentation. Proceedings of the Biological Society of Washington. 1998:111:781-94.

8. Morandini AC, Ascher D, Stampar SN, Ferreira JFV. Cubozoa e Scyphozoa (Cnidária: Medusozoa) de águas costeiras do Brasil. Ineringia Ser Zool. 2005;95: 281-94

9. Morandini AC, Soares MO, Mathews-Cascon H, Marques AC. A survey of the Scyphozoa and Cubozoa (Cnidaria, Medusozoa) fron the Ceará coast (NE Brazil). Biota Neotropica. 2006:6:1-8.

10. Burnett JW, Kumar S, Malecki JM, Szmant AM. The antibody response in seabather's eruption. Toxicon. 1995;33:99-104.

MAILING ADDRESS:

André Luiz Rossetto

Av. Alvin Bauer, 655 Sala 203 - Centro Médico Vida 88330-643 Balneário Camboriú, SC

Phone: (47) 33673407

E-mail: rossettovida@terra.com.br

How to cite this article: Rossetto AL, Proença LAO. Seabather's eruption: report of case in northeast region of Brazil. An Bras Dermatol. 2012;87(3):472-4. 